\title{
IMPLEMENTASI METODE SUPPORT VECTOR MACHINE UNTUK INDENTIFIKASI PENYAKIT DAUN TANAMAN KUBIS
}

\author{
Ariadi Retno Tri Hayati Ririd ${ }^{1}$, Ayundha Wulan Kurniawati ${ }^{2}$, Yoppy Yunhasnawa ${ }^{\mathbf{3}}$ \\ 1,2,3 Jurusan Teknologi Informasi, Politeknik Negeri Malang \\ ${ }^{1}$ faniri4education@gmail.com, ${ }^{2}$ ayundhawulan@gmail.com, ${ }^{3}$ yunhasnawa@gmail.com
}

\begin{abstract}
Abstrak
Tanaman kubis merupakan salah satu sayuran yang banyak dikonsumsi masyarakat, dalam produksi bibit tanaman kubis sering mengalami hambatan karena serangan hama. Salah satu komponen dalam keberhasilan produksi kubis adalah masa perkembangan bibit, yang dikhawatirkan banyak mendapat serangan hama. Dalam penelitian ini pengolahan citra digital digunakan untuk mengidentifikasi hama/penyakit terhadap bibit tanaman kubis. Penelitian ini dimulai dengan pengumpulan citra daun tanaman kubis. Tahapan selanjutnya adalah preprocessing citra dengan menghilangkan background dari citra masukan kemudian dilakukan proses grayscale untuk mendapatkan nilai yang akan digunakan untuk proses selanjutnya. Hasil tersebut kemudian akan dihitung dengan menggunakan metode Support Vector Machine (SVM). Proses training dilakukan dengan Sequential Training yang kemudian dilakukan proses testing. Hasil dari klasifikasi dipengaruhi oleh proses segmentasi yang dilakukan serta input parameter yang digunakan saat proses training. Dari hasil pengujian menunjukkan rata-rata akurasi hasil klasifikasi mencapai $80.55 \%$.
\end{abstract}

Kata kunci : support vector machine, pengolahan citra, daun kubis, klasifikasi

\section{Pendahuluan}

Bercak daun dan busuk hitam merupakan penyakit yang menyeranng daun tanaman kubis dan menimbulkan kerugian sehingga produksi kubis mengalami penurunan. Identifikasi penyakit daun tanaman kubis dilakukan secara manual dengan mengamati gejala yang tampak pada daun. Penyakit bercak daun ditandai dengan munculnya gejala bercak-bercak bulat coklat dan lingkaran konsentris. Penyakit busuk hitam ditandai dengan munculnya bercak kuning di sepanjang tepi daun yang mengarah ke tengan daun.

Dalam proses pengendalian hama dan penyakit tanaman diperlukan kegiatan pemantauan untuk memantau perkembangan dari bibit tanaman kubis serta untuk memantau penyakit dan hama yang menyerang sehingga diperlukan kemampuan untuk mengidentifikasi penyakit. Proses identifikasi penyakit dilakukan secara manual dengan cara pengamatan visual secara langsung pada daun tanaman kubis.

Pengolahan citra digital dapat digunakan untuk mengidentifikasi penyakit daun tanaman kubis. Karena tidak semua petani memiliki pemahaman detail mengenail penyakit yang menyerang tanaman dan petani tidak perlu menghafal gejala penyakit yang merugikan dan tidak merugikan.

Sistem dapat mengenali penyakit daun dengan menggunakan citra digital dari daun tanaman kubis yang berpenyakit. Data citra digital daun tanaman kubis digunakan untuk melakukan proses pelatihan bagi sistem sehingga dapat mengenali penyakit, hasil dari proses pelatihan dapat digunakan untuk mengidentifikasi penyakit pada data uji.

Untuk mengidentifikasi penyakit diperlukan proses klasifikasi. Klasifikasi merupakan salah satu cara untuk pengelompokan objek terhadap sebuah kelas tertentu. Terdapat beberapa metode yang digunakan untuk klasifikasi, di antaranya adalah Naive Bayes, K-Nearest Neighbor (KNN), Support Vector Machine (SVM), Artificial Neural Network (ANN) (Prasetyo, 2012). Pengolahan data citra digital daun tanaman kubis diperlukan untuk proses klasifikasi.

Terdapat perbedaan warna antara daun berpenyakit busuk hitam dan bercak daun sehingga perlu adanya ekstraksi warna. Grayscale merupakan merupakan citra digital yang hanya memiliki satu nilai kanal pada setiap pikselnya, atau nilai bagian Red $=$ Green $=$ Blue . Nilai tersebut digunakan untuk menunjukkan tingkat intensitas. Warna yang dimiliki adalah warna dari hitam, keabuan, dan putih. Tingkatan keabuan merupakan warna abu dengan berbagai tingkatan dari hitam hingga mendekati putih (Sutoyo, 2009).

Tahap awal penelitian adalah pengumpulan data citra daun tanaman kubis berpenyakit. Tahap selanjutnya adalah preprocessing citra dengan menghilangkan background citra untuk mengubah citra menjadi citra grayscale pada objek daun tanaman kubis.

Proses identifikasi penyakit daun tanaman kubis menggunakan metode SVM dengan 
menggunakan Sequential Training dengan menghitung nilai yang didapatkan dari preprocessing. Proses identifikasi dilakukan berdasarkan warna yang diambil dari citra daun tanaman kubis dengan menggunakan grayscale, yang menghasilkan nilai keabuan dari objek citra daun tanaman kubis.

\section{Tinjauan Pustaka}

\subsection{Tanaman Kubis}

Kubis merupakan tanaman herba semusim berbatang pendek dan memiliki ruas yang merupakan tempat duduknya daun. Pada bibit, perbedaan antar jenis tanaman sulit dibedakan. Namun setelah tumbuh beberapa waktu, tanaman baru dapat dibedakan berdasarkan ciri masingmasing tanaman. Bunga kubis memiliki mahkota berwarna kuning dan tersusun dalam tandan, penyerbukannya dibantu oleh serangga. Biji yang terdapat di dalam buah yang berupa silique (polong). Biji tersebut berukuran kecil, berbentuk bulat, dan berwarna kecokelatan(Vidyani, 2013).

\subsection{Klasifikasi}

Klasifikasi merupakan suatu proses pengelompokkan objek ke dalam suatu kelas tertentu. Klasifikasi memiliki tujuan untuk menentukan kelas suatu objek yang belum diketahui kelasnya. Terdapat dua data yang dijadikan acuan dalam proses klasifikasi yaitu data training dan data testing. Data training merupakan data masukan yang berguna sebagai data latih dari model. Sedangkan data testing merupakan data yang digunakan untuk uji coba dari pemodelan yang masih belum memiliki kelas tertentu. Banyak metode yang terkait dengan klasifikasi, di antaranya adalah Naive Bayes, $K$ Nearest Neighbor (KNN), Support Vector Machine (SVM), Artificial Neural Network (ANN)(Prasetyo, 2012).

\subsection{Citra Digital}

Citra Digital merupakan sebuah larik (array) yang berisikan nilai-nilai real maupun komplek yang direpresentasikan dengan deretan bit tertentu. Citra dapat di definisikan sebagai fungsi $f(x, y)$ berukuran $\mathrm{M}$ barisa dan $\mathrm{N}$ kolom, dengan $\mathrm{x}$ dan $\mathrm{y}$ adalah koordinat spasial, dan amplitude $\mathrm{f}$ di titik koordinat $(\mathrm{x}, \mathrm{y})$ dinamakan intensitas atau tingkat keabuan dari citra pada titik tersebut.

Nilai suatu piksel memiliki nilai dalam rentang tertentu, dari nilai minimum sampai nilai maksimum. Jangkauan yang digunakan berbedabeda tergantung dari jenis warnanya.

Pengolahan citra digital adalah sebuah disiplin ilmu yang mempelajari hal-hal yang berkaitan dengan perbaikan kualitas gambar (peningkatan kontras, transformasi warna, restorasi citra), transformasi gambar (rotasi, translasi, skala, transformasi geometrik), melakukan pemilihan citra ciri (feature images) yang optimal untuk tujuan analisis, melakukan proses penarikan informasi atau deskripsi objek atau pengenalan objek yang terkandung pada citra, melakukan kompresi atau reduksi data untuk tujuan penyimpanan data, transmisi datam dan waktu proses data. Input dari pengolahan citra adalah citra sedangkan output berupa citra hasil pengolahan(Dewi, 2014).

\subsection{Thresholding}

Proses thresholding merupakan proses mengubah citra berderajat keabuan menjadi citra biner atau hitam putih sehingga dapat diketahui daerah mana yang termasuk objek dan background dari citra secara jelas. Citra hasil thresholding biasanya digunakan lebih lanjut untuk proses pengenalan obyek serta ekstraksi fitur(Sutoyo, 2009).

$\mathrm{g}(\mathrm{x}, \mathrm{y})=\left\{\begin{array}{l}1 \text { if } f(x, y) \geq T \\ 0 \text { if } f(x, y)<T\end{array}\right\}$

\subsection{Support Vector Machine (SVM)}

Konsep SVM dapat dijelaskan secara sederhana sebagai usaha mencari hyperplane terbaik yang berfungsi sebagai pemisah dua buah kelas pada input space . Pattern yang merupakan anggota dari dua buah kelas: +1 dan -1 dan berbagi alternatif garis pemisah (discrimination boundaries). Margin adalah jarak antara hyperplane tersebut dengan pattern terdekat dari masing-masing kelas. Pattern yang memiliki jarak paling dekat disebut sebagai support vector. Usaha untuk mencari lokasi hyperplane merupakan inti dari proses pembelajaran pada SVM(Putra, 2010).
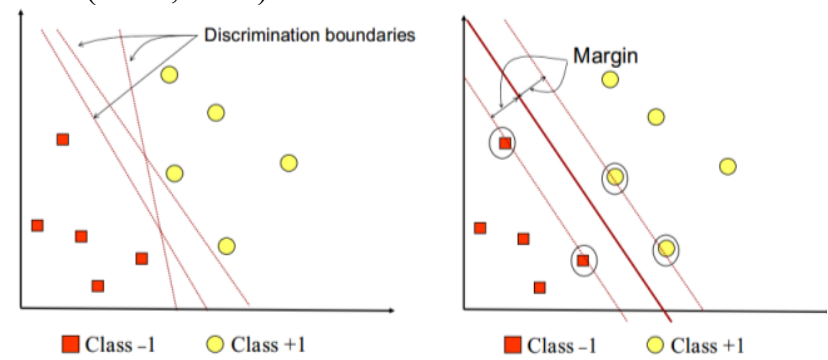

Gambar 1. Hyperplane yang memisahkan dua kelas

Hyperplane dinyatakan dengan persamaan (2) :

$w \cdot x+b=0$

Pada gambar 1 terdapat dua kelas yang dipisahkan oleh dua bidang pembatas secara sejajar. Yaitu kelas +1 dan kelas -1 . Data kelas +1 dinyatakan dengan lingkaran berwarna kuning, dan data kelas -1 dinyatakan dengan lingkaran berwarna 
merah. Bidang pembatas dinyatakan dengan $\mathrm{H} . \mathrm{H}_{1}$ dinyatakan sebagai bidang pembatas pada kelas +1 dan $\mathrm{H}_{2}$ dinyatakan sebagai bidang pembatas kelas 1. Yang dinyatakan dengan persamaan (3) dan (4) : w. $x_{i}+b \geq+1$ for $y_{i}=+1$

$w \cdot x_{i}+b \geq-1$ for $y_{i}=-1$

Sehingga didapatkan persamaan (5):

$y_{i}\left(x_{i} \cdot w+b\right) \geq 1$

Jika titik terpisah secara linear fungsi untuk permukaan ini ditentukan dengan persamaan (6):

$$
\begin{gathered}
\mathrm{f}(\mathrm{x})=\left(\sum_{i=1}^{n} \alpha_{i}^{*} y_{i}\left(x_{i}, x\right)+b^{*}\right) \\
\left(x_{i}, y_{i}\right) \in R^{N} x\{-1,1\}
\end{gathered}
$$

Jika kelas tidak terpisah secara linear maka fungsi untuk permukaan ditentukan oleh persamaan (7):

$$
\mathrm{f}(\mathrm{x})=\left(\sum_{\mathrm{i}=1}^{n} \alpha_{i}^{*} y_{\mathrm{i}} k(x, y)+b^{*}\right)
$$

Terdapat beberapa fungsi kernel yang digunakan untuk menyelesaikan masalah pada SVM non linear dapat dilihat pada persamaan berikut ini:

a. Fungsi Kernel Linear

$$
k(x, y)=x \cdot y
$$

b. Fungsi Kernel Polinomial

$$
k(x, y)=(1+x, y)^{q}, q=1,2, \ldots, N
$$

c. Fungsi Kernel Radial Basis

$$
k(x, y)=\exp \frac{\left(-|| x-y||^{2}\right)}{2 \sigma^{q}}
$$

Langkah-langkah yang digunakan untuk melakukan training adalah sebagai berikut:

a. Melakukan perhitungan kernel dan inisialisasi parameter-parameter SVM seperti nilai $\alpha_{i}=0$; $\varepsilon=0,0001 ; \gamma=0,01 ; \lambda=1 ; \mathrm{C}=1$; serta nilai iterasi maksimal $=5$;

b. Menghitung Matriks Hessian dengan persamaan

(11)

$$
D_{i j}=y_{i} y_{j}\left(k\left(x_{i}, x_{j}\right)+\lambda^{2}\right)
$$

c. Menghitung nilai $E_{i}$ menggunakan persamaan

$$
E_{i}=\sum_{j=1}^{n} \alpha_{i} D_{i j}
$$

d. Menghitung nilai $\gamma$ dan $\delta \alpha_{\mathrm{i}}$ menggunakan persamaan (13) dan (14)

$$
\gamma=\frac{\text { konstanta }}{\max D i j}
$$

$$
\delta \alpha_{i}=\min \left[\max \left[\gamma\left(1-E_{i}\right), \alpha_{i}\right], C-\alpha_{i}\right]
$$

e. Memperbarui nilai $\alpha_{i}$ menggunakan persamaan (15)

$$
\alpha_{i}=\alpha_{i}+\delta \alpha
$$

f. Menghitung nilai w. $\mathrm{x}^{+}$dan W. $\mathrm{x}^{-}$untuk mendapatkan nilai bias menggunakan persamaan (16) hingga (18)

$$
\begin{aligned}
& w \cdot x^{+}=\alpha_{i} \cdot \gamma_{i} \cdot K\left(x, x^{+}\right) \\
& w \cdot x^{-}=\alpha_{i} \cdot \gamma_{i} \cdot K\left(x, x^{-}\right) \\
& \mathrm{b}=-\frac{1}{2}\left(w \cdot x^{+}+w \cdot x^{-}\right)
\end{aligned}
$$

Langkah-langkah yang dilakukan untuk melakukan testing:

a. Menghitung nilai $K\left(x, x_{i}\right)$ yang kemudian digunakan untuk menghitung nilai weight.

$\mathrm{K}\left(\mathrm{x}, \mathrm{x}_{\mathrm{i}}\right)=\exp \frac{\left(-|| x-y \|^{2}\right)}{2 \sigma^{q}}$

b. Menghitung nilai weight dengan alpha yang didapatkan dari proses training.

$w \cdot x=\alpha_{i} \cdot \gamma_{i} \cdot K\left(x, x_{i}\right)$

c. Menghitung nilai $f(x)$ dengan menggunakan persamaan (21)

$$
\begin{aligned}
& f(x)=\sum_{j=1}^{n}=\alpha_{i} \gamma_{i} K\left(x_{i}, x\right)+b \\
& \text { klasifikasi }=\operatorname{sign}(-(f(x)))
\end{aligned}
$$

d. Hasil perhitungan dari proses testing berupa nilai -1 dan 1 .

e. Setelah semua data testing dihitung dengan semua kelas yang ada maka untuk menentukan kelas dilakukan dengan menghitung jumlah hasil perhitungan testing terbanyak masuk ke kelas yang mana.

\subsection{Evaluasi}

Evaluasi bertujuan utnuk mengetahui tingkat akurasi dari hasil penggunaan metode Support Vector Machine (SVM) dengan cara menghitung jumlah data uji yang kelasnya diprediksi secara benar. Metode perhitungan tingkat akurasi sebagai pengujian dan evaluasi sistem. Teori evaluasi yang (11)ligunakan adalah dengan melakukan pendekatan statistik. Menurut Han dan Kamber (2006) untuk mengukur akurasi dan ketepatan model dapat dilkaukan dengan menghirung perbandingan jumlah

(12ketepatan model dapat dilakukan dengan menghitung perbandingan jumlah prediksi benar terhadap seluruh record yang dapat diprediksi. Untuk formulasi jumlah testing data yang tepat dikenali dan jumlah seluruh data testing kemudian dikalikan $100 \%$. Secara matematis dapat dirumuskan sebagai berikut(Putra, 2010): 
Akurasi $=\frac{\text { Jumlah Prediksi Benar }}{\text { Total Prediksi }} \times 100 \%$

\section{Implementasi}

Tahapan penelitian yang dilakukan untuk proses pembuatan perangkat lunak yang dilakukan oleh penulis yang ditunjukkan pada Gambar 2 .

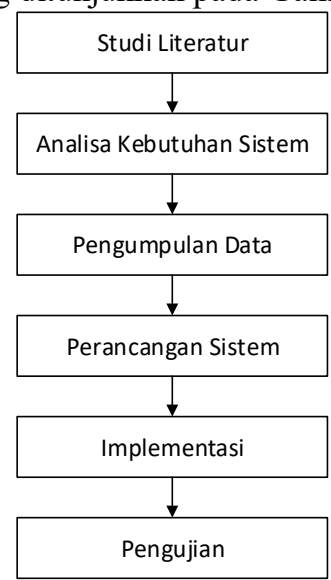

Gambar 2. Diagram Blok Metodologi Penelitian

Berikut merupakan alur dari sistem yang dilakukan ditunjukkan pada Gambar 3:

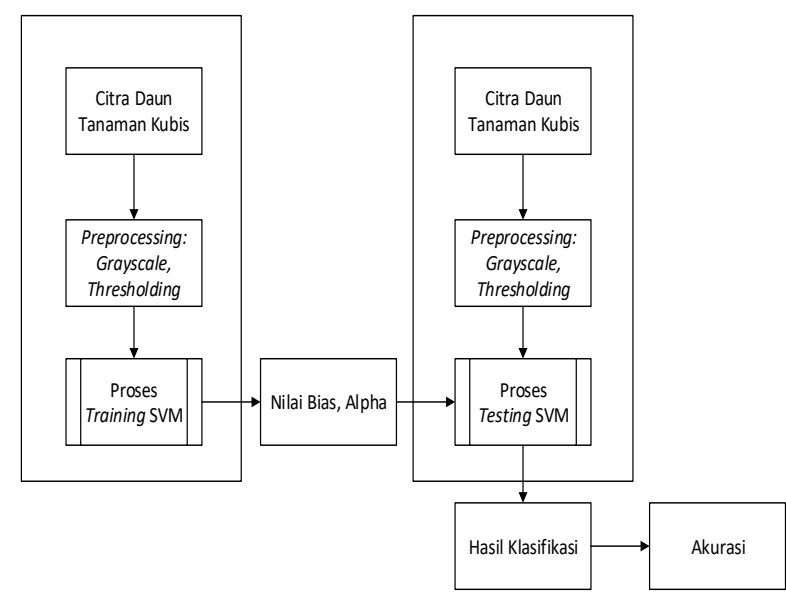

Gambar 3. Diagram Blok Identifikasi Penyakit Daun Tanaman Kubis

Data masukan untuk penelitian ini adalah citra digital daun tanaman kubis berpenyakit dengan keluaran berupa hasil klasifikasi. Proses dimulai dengan input citra digital daun tanaman kubis. Selanjutnya dilakukan proses praprosesing citra yaitu dengan ekstraksi fitur warna yaitu dengan mengubah citra masukan menjadi citra Grayscale.

Selanjutnya dilakukan proses thresholding global, untuk kemudian dilakukan proses klasifikasi SVM yang terbagi menjadi dua yaitu proses pelatihan proses pengujian.

Berikut ini merupakan diagram blok dari proses training:

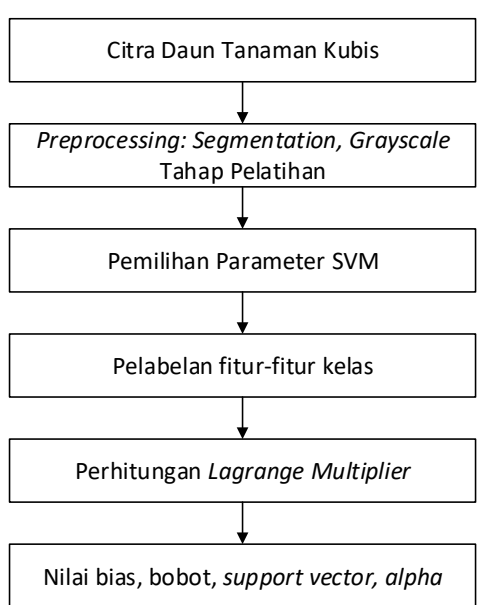

Gambar 4. Diagram Blok Proses Training SVM

Pada gambar 4 menunjukkan mengenai proses pelatihan SVM akan dipilih parameter parameter yang digunakan untuk nilai tingkat akurasi dalam pencapaian nilai optimal. Proses pemberian label fitur-fitur kedalam sejumlah kelas. Perhitungan nilai Lagrange Multiplier untuk mencari nilai optimasi global terhadap nilai dan jumlah support vector. Setelah itu menghitung nilai nilai bias dan bobot untuk mendapatkan fungsi hyperplane.

Berikut ini merupakan diagram blok dari proses testing:

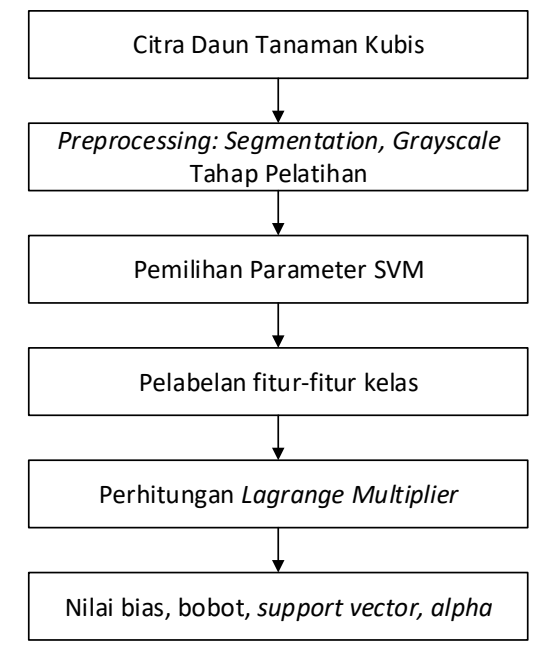

Gambar 5. Diagram Blok Proses Testing SVM

Pada gambar 5 menunjukkan mengenai proses pengujian SVM dimulai dengan memasukkan fungsi hyperplane dari proses pelatihan, serta banyak data uji. Kemudian akan dihitung nilai kernel dari data training dengan data testing. Selanjutnya menghitung nilai $\mathrm{w}$ dan menjumlahkan semua nilai w untuk setiap data training. Kemudian akan di lakukan proses perhitungan klasifikasi.

Sistem yang akan dibuat mulai dari tahapan masukan citra daun, praposesing citra dengan mengubah menjadi citra grayscale kemudian dilakukan proses thresholding, yang kemudian akan dilakukan proses klasifikasi dengan metode SVM. 
Setelah dilakukan perhitungan kernel RBF selanjutnya adalah perhitungan sequential training. Langkah pertama adalah inisialisasi parameterparameter SVM. Inisialisasi nilai misalnya $\alpha \mathrm{i}=0 ; \varepsilon$ $=0,001 ; \gamma=0,01 ; \lambda=1 ; \mathrm{C}=1$; dan nilai iterasi maksimal $=2$.

Pengujian ini dilakukan untuk melihat pengaruh parameter pada Sequential Training terhadap nilai akurasi sistem. Pengujian ini bertujuan untuk mendapatkan nilai parameter yang memberi nilai akurasi terbaik. Berikut ini merupakan hasil pengujian klasifikasi daun tanaman kubis yang ditunjukkan pada Tabel 1.

Tabel 1 Pengujian Klasifikasi Daun Tanaman Kubis

\begin{tabular}{|c|c|c|c|}
\hline No. & Citra Daun & Manual & Output \\
\hline 1. & & $\begin{array}{l}\text { Bercak } \\
\text { Daun }\end{array}$ & $\begin{array}{l}\text { Bercak } \\
\text { Daun }\end{array}$ \\
\hline 2. & & $\begin{array}{l}\text { Bercak } \\
\text { Daun }\end{array}$ & $\begin{array}{l}\text { Busuk } \\
\text { Hitam }\end{array}$ \\
\hline 3. & & $\begin{array}{l}\text { Bercak } \\
\text { Daun }\end{array}$ & $\begin{array}{c}\text { Bercak } \\
\text { Daun }\end{array}$ \\
\hline 4. & & $\begin{array}{l}\text { Bercak } \\
\text { Daun }\end{array}$ & $\begin{array}{l}\text { Bercak } \\
\text { Daun }\end{array}$ \\
\hline 5. & & $\begin{array}{l}\text { Busuk } \\
\text { Hitam }\end{array}$ & $\begin{array}{l}\text { Busuk } \\
\text { Hitam }\end{array}$ \\
\hline 6. & & $\begin{array}{l}\text { Bercak } \\
\text { Daun }\end{array}$ & $\begin{array}{l}\text { Bercak } \\
\text { Daun }\end{array}$ \\
\hline 7. & & $\begin{array}{l}\text { Busuk } \\
\text { Hitam }\end{array}$ & $\begin{array}{l}\text { Busuk } \\
\text { Hitam }\end{array}$ \\
\hline 8. & & $\begin{array}{l}\text { Busuk } \\
\text { Hitam }\end{array}$ & $\begin{array}{l}\text { Busuk } \\
\text { Hitam }\end{array}$ \\
\hline
\end{tabular}

\begin{tabular}{|c|c|c|c|}
\hline No. & Citra Daun & Manual & Output \\
\hline 9. & & $\begin{array}{l}\text { Busuk } \\
\text { Hitam }\end{array}$ & $\begin{array}{l}\text { Busuk } \\
\text { Hitam }\end{array}$ \\
\hline 10 & & $\begin{array}{c}\text { Busuk } \\
\text { Hitam }\end{array}$ & $\begin{array}{c}\text { Busuk } \\
\text { Hitam }\end{array}$ \\
\hline 11 & & $\begin{array}{l}\text { Busuk } \\
\text { Hitam }\end{array}$ & $\begin{array}{l}\text { Busuk } \\
\text { Hitam }\end{array}$ \\
\hline 12 & & $\begin{array}{l}\text { Bercak } \\
\text { Daun }\end{array}$ & $\begin{array}{c}\text { Bercak } \\
\text { Daun }\end{array}$ \\
\hline 13. & & $\begin{array}{l}\text { Bercak } \\
\text { Daun }\end{array}$ & $\begin{array}{c}\text { Bercak } \\
\text { Daun }\end{array}$ \\
\hline 14. & & $\begin{array}{l}\text { Bercak } \\
\text { Daun }\end{array}$ & $\begin{array}{c}\text { Bercak } \\
\text { Daun }\end{array}$ \\
\hline 15. & & $\begin{array}{l}\text { Bercak } \\
\text { Daun }\end{array}$ & $\begin{array}{l}\text { Busuk } \\
\text { Hitam }\end{array}$ \\
\hline 16. & & $\begin{array}{l}\text { Bercak } \\
\text { Daun }\end{array}$ & $\begin{array}{c}\text { Bercak } \\
\text { Daun }\end{array}$ \\
\hline 17. & & $\begin{array}{l}\text { Bercak } \\
\text { Daun }\end{array}$ & $\begin{array}{l}\text { Busuk } \\
\text { Hitam }\end{array}$ \\
\hline 18. & & $\begin{array}{l}\text { Bercak } \\
\text { Daun }\end{array}$ & $\begin{array}{c}\text { Busuk } \\
\text { Hitam }\end{array}$ \\
\hline 19. & & $\begin{array}{l}\text { Busuk } \\
\text { Hitam }\end{array}$ & $\begin{array}{l}\text { Busuk } \\
\text { Hitam }\end{array}$ \\
\hline
\end{tabular}




\begin{tabular}{|c|c|c|c|}
\hline No. & Citra Daun & Manual & Output \\
\hline 20. & & $\begin{array}{l}\text { Busuk } \\
\text { Hitam }\end{array}$ & $\begin{array}{l}\text { Busuk } \\
\text { Hitam }\end{array}$ \\
\hline 21. & & $\begin{array}{l}\text { Busuk } \\
\text { Hitam }\end{array}$ & $\begin{array}{l}\text { Busuk } \\
\text { Hitam }\end{array}$ \\
\hline 22. & & $\begin{array}{l}\text { Busuk } \\
\text { Hitam }\end{array}$ & $\begin{array}{c}\text { Busuk } \\
\text { Hitam }\end{array}$ \\
\hline 23. & & $\begin{array}{l}\text { Bercak } \\
\text { Daun }\end{array}$ & $\begin{array}{c}\text { Bercak } \\
\text { Daun }\end{array}$ \\
\hline 24. & & $\begin{array}{l}\text { Busuk } \\
\text { Hitam }\end{array}$ & $\begin{array}{l}\text { Busuk } \\
\text { Hitam }\end{array}$ \\
\hline 25 & & $\begin{array}{l}\text { Bercak } \\
\text { Daun }\end{array}$ & $\begin{array}{l}\text { Bercak } \\
\text { Daun }\end{array}$ \\
\hline 26 & & $\begin{array}{l}\text { Bercak } \\
\text { Daun }\end{array}$ & $\begin{array}{l}\text { Bercak } \\
\text { Daun }\end{array}$ \\
\hline 27. & & $\begin{array}{l}\text { Busuk } \\
\text { Hitam }\end{array}$ & $\begin{array}{l}\text { Bercak } \\
\text { Daun }\end{array}$ \\
\hline 28. & & $\begin{array}{l}\text { Busuk } \\
\text { Hitam }\end{array}$ & $\begin{array}{c}\text { Bercak } \\
\text { Daun }\end{array}$ \\
\hline 29. & & $\begin{array}{l}\text { Bercak } \\
\text { Daun }\end{array}$ & $\begin{array}{c}\text { Bercak } \\
\text { Daun }\end{array}$ \\
\hline 30. & & $\begin{array}{l}\text { Busuk } \\
\text { Hitam }\end{array}$ & $\begin{array}{c}\text { Bercak } \\
\text { Daun }\end{array}$ \\
\hline
\end{tabular}

\begin{tabular}{|c|c|c|c|}
\hline No. & Citra Daun & Manual & Output \\
\hline 31. & & $\begin{array}{l}\text { Busuk } \\
\text { Hitam }\end{array}$ & $\begin{array}{c}\text { Busuk } \\
\text { Hitam }\end{array}$ \\
\hline 32. & & $\begin{array}{l}\text { Busuk } \\
\text { Hitam }\end{array}$ & $\begin{array}{c}\text { Busuk } \\
\text { Hitam }\end{array}$ \\
\hline 33. & & $\begin{array}{l}\text { Bercak } \\
\text { Daun }\end{array}$ & $\begin{array}{c}\text { Bercak } \\
\text { Daun }\end{array}$ \\
\hline 34. & & $\begin{array}{l}\text { Bercak } \\
\text { Daun }\end{array}$ & $\begin{array}{l}\text { Bercak } \\
\text { Daun }\end{array}$ \\
\hline 35. & & $\begin{array}{l}\text { Busuk } \\
\text { Hitam }\end{array}$ & $\begin{array}{l}\text { Busuk } \\
\text { Hitam }\end{array}$ \\
\hline 36. & & $\begin{array}{l}\text { Busuk } \\
\text { Hitam }\end{array}$ & $\begin{array}{c}\text { Busuk } \\
\text { Hitam }\end{array}$ \\
\hline
\end{tabular}

Pada proses perhitungan training terdapat inputan parameter yang digunakan. Nilai-nilai parameter yang digunakan tersebut mempengaruhi proses Sequential Training secara keseluruhan mulai dari proses perhitungan Matriks Hessian, Nilai Error, Delta Alpha, Alpha, Nilai Gamma baru, Nilai $(x, x i)$, Nilai $w$ dan Nilai Bias yang mempengaruhi proses klasifikasi. Dengan menggunakan nilai parameter terbaik maka sistem diharapkan mampu menghasilkan klasifikasi dengan akurasi yang lebih baik.

Berdasarkan pengujian nilai-nilai parameter didapatkan nilai pengujian yang menghasilkan nilai akurasi terbesar dari tiap-tiap pengujian yang ditunjukkan pada Tabel 2.

Tabel 2 Parameter yang digunakan

\begin{tabular}{|l|l|}
\hline Parameter & Nilai \\
\hline Lambda & $0.4,0.5$ \\
\hline Gamma & $0.4,0.5$ \\
\hline C & 5 \\
\hline Sigma & 4,5 \\
\hline Epsilon & 0.01 \\
\hline Maximal Iteration & 25 \\
\hline
\end{tabular}


Tabel 3 merupakan confusion matrix yang menunjukkan perhitungan nilai precision dan recall.

Tabel 3. Confusion Matrix hasil pengujian

\begin{tabular}{|c|c|c|}
\hline $\mathbf{n}=\mathbf{3 6}$ & \multicolumn{2}{|c|}{ Predicted Class } \\
\hline Actual Class & $\begin{array}{c}\text { Class 1 } \\
\text { (Bercak Daun) }\end{array}$ & $\begin{array}{c}\text { Class 2 } \\
\text { (Busuk } \\
\text { Hitam) }\end{array}$ \\
\hline $\begin{array}{c}\text { Class 1 } \\
\text { (Bercak Daun) }\end{array}$ & $\mathrm{TP}=14$ & $\mathrm{FN}=4$ \\
\hline $\begin{array}{c}\text { Class 2 (Busuk } \\
\text { Hitam) }\end{array}$ & $\mathrm{FP}=3$ & $\mathrm{TN}=15$ \\
\hline
\end{tabular}

$$
\begin{aligned}
& \text { Precision }=\frac{\mathrm{TP}}{(\mathrm{FP}+\mathrm{TP})} \times 100 \% \\
& =\frac{14}{(3+14)} \times 100 \%=82.35 \% \\
& \text { Recall }=\frac{\mathrm{TP}}{(\mathrm{TP}+\mathrm{FN})} \times 100 \% \\
& =\frac{14}{(14+4)} \times 100 \%=77.78 \% \\
& \text { Akurasi }=\frac{(\mathrm{TP}+\mathrm{TN})}{(\mathrm{TP}+\mathrm{TN}+\mathrm{FP}+\mathrm{FN})} \times 100 \% \\
& =\frac{(14+15)}{(14+15+3+4)} \times 100 \%=80.55 \%
\end{aligned}
$$

Proses dengan menggunakan histogram equalization yang digunakan untuk memperbaiki citra masukan kemudian selanjutnya dapat dilakukan proses segmentasi untuk mendapatkan citra masukan yang akan diolah untuk perhitungan training dan testing, menghasilkan akurasi sebesar $80.55 \%$.

Tingkat kerberhasilan identifikasi penyakit daun tanaman kubis dengan menggunakan metode SVM dipengaruhi oleh proses segmentasi dan parameter masukan yang digunakan saat training. Dengan proses segmentasi yang baik akan menghasilkan klasfikasi yang lebih bagus, penggunaan parameter terbaik juga mampu meningkatkan hasil klasifikasi.

\section{Kesimpulan dan Saran}

Proses yang dilakukan untuk melakukan identifikasi penyakit daun tanaman kubis dengan metode Support Vector Machine adalah mengumpulkan data citra daun tanaman kubis. Selanjutnya proses identifikasi dimulai dengan memproses citra dengan menghilangkan background citra dengan tujuan membedakan foreground dan background kemudian mengubah citra menjadi grayscale. Hasil dari proses grayscale tersebut kemudian disimpan di database, setelah semua citra yang digunakan untuk training selesai di segmentasi kemudian diproses untuk perhitungan training. Untuk proses testing langkah awal yang dilakukan sama dengan proses training yaitu memproses citra dengan menghilangkan background citra dengan tujuan membedakan foreground dan background kemudian mengubah citra menjadi grayscale. Hasil dari proses grayscale tersebut kemudian akan dihitung dengan nilai yang didapatkan dari proses training. Proses testing akan menghasilkan klasifikasi dari citra yang digunakan sebagai data testing.

Identifikasi penyakit daun tanaman kubis dengan mengimplementasikan metode Support Vector Machine memperoleh tingkat akurasi terbesar dengan nilai parameter yang digunakan adalah $\varepsilon=0.01, \gamma=0.4$ dan $0.5, \lambda=0.4$ dan $0.5, \mathrm{C}=$ 5 , dan iterasi maksimal $=25$. Tingkat kerberhasilan identifikasi penyakit daun tanaman kubis dengan menggunakan metode SVM dipengaruhi oleh proses segmentasi dan parameter masukan yang digunakan saat training. Dengan proses segmentasi yang baik akan menghasilkan klasfikasi yang lebih bagus, penggunaan parameter terbaik mampu meningkatkan hasil klasifikasi, dengan menggunakan Histogram Equalization dan nilai parameter terbaik untuk proses perhitungan training hasil akurasi yang didapatkan sebesar $80.55 \%$

\section{Daftar Pustaka:}

Prasetyo, Eko. 2012. "DATA MINING - Konsep dan Aplikasi Menggunakan MATLAB". Yogyakarta: Andi.

Vidyani, Faradina. 2013. "Identifikasi Penyakit Tanaman Kubis menggunakan Gaussian Filter dan Wavelet". Diakses dari http://repository.ipb.ac.id/jspui/handle/1234567 $89 / 66550$ pada tanggal 14 Desember 2016 pukul 15.03 .

Dewi, Ratih Kartika dan Ginardi, R.V. 2014. "Identifikasi Penyakit pada Daun Tebu dengan Gray Level Co-occurrence Matrix dan Color Moments". Diakses dari http://jtiik.ub.ac.id/index.php/jtiik/article/view/1 14 pada tanggal 14 Desember 2016 pukul 14:30.

Sutoyo, T., dkk. 2009. "Teori Pengolahan Citra Digital". Yogyakarta: Penerbit Andi.

Putra, Darma. 2010. "Pengolahan Citra Digital". Yogyakarta: Andi.

Zulkarnaen, Haji. "Budidaya Sayuran Tropis". 2013. Jakarta: Bumi Aksara. 62-96.

Semangun, Haryono. 2007. "Penyakit-penyakit Tanaman Holtikultura di Indonesia". Yogyakarta: Gadjah Mada University Press. 171-194.

Arbawa, Yoke Kusuma. 2016. "Implementasi Metode Support Vector Machine (SVM) untuk Identifikasi Penyakit pada Citra Daun Tanaman Kacang Tanah Menggunakan Gray Level Cooccurrence Matrix (GLCM)". Malang. Universitas Brawijaya 
Nugroho, Anto S., et al. 2003. "Support Vector Machine : Teori dan Aplikasinya dalam Bioinformatika". Ilmukomputer.

Musicant, D.R., Kumar, V., dan Ozgur, A. 2003. "Optimizing F-Measure with Support Vector Machines". Florida: FLAIRS (The Florida Artificial Intelligence Research Society. 356360 
Volume 4, Edisi 3, Mei 2018 